\title{
MEKÂNLA BELIRLENEN YAŞAMLAR: GÜVENLIKLİ KONUTLARDA YAŞAMAK
}

\author{
LIVES DETERMINED BY PLACES: LIVING IN GATED RESIDENTIAL PLACES
}

\author{
Yakup AZAK $^{1}$ - Göklem TEKDEMIR ${ }^{2}$
}

\section{Öz}

Bu çalışmada, gündelik hayata "sadece ev değil bir yaşam tarzı satın alma" söylemiyle dahil olan güvenlikli ve kapalı konutların, kendi sakinlerinin yaşam tarzlarında ne tür yeni düzenlemelere yol açtı̆̆ sorusuna odaklandık. Sakinlerinin konut yaşamı dışındakiler ile sosyal karşılaştırmaları, tüketim, sosyal ve mekân bağlamında yeni kimlik inşalarına sosyal psikolojik perspektiften açıklamalar getirdik. Çalışma için, İstanbul'un farklı ilçelerindeki güvenlik elemanlı kapalı konut yaşam alanı sakini farklı politik yönelim ve sosyo-demografik özelliklere sahip toplam yedi evli çiftle görüşmeler yaptık. Odak grup görüşme tekniği ile topladığımız verileri, Maxqda 2018 programı üzerinden kategori aşamalı tematik analiz yöntemi ile analiz ettik.

Katılımcıların konut yaşamını, şehir hayatında zorunlu bir ihtiyacı karşılayan tüketim olarak anlamlandırdıklarını gözlemledik. Bu zorunlu algıladıkları tüketim pratiği içinde, çocuk yetiştirirken yaşanan endişe ve korku ile şehir hayatında kendini değerli hissetmek gibi duygu deneyimlerinin birlikte yaşandıklarını tespit ettik. Mekânın güvenlik işleyişleri, fiziksel imkânları, yüksek duvarlarla çevrili kapalı alan mimarisi, sakinlerine güvenli ve ayrıcalıklı olma hissi dışında izole olma, hapsolma da içeren sembolik anlamlandırmalara neden olmaktadır.

Temelde iddiamız bu mekanların kendi sakinlerini çeşitli olumsuz duygu deneyiminden uzak tutma iddiasıyla mekâna özgü yeni normlarla sakinlerinin yaşam tarzlarında yeni düzenlemelere ve değişimlere gitmelerine neden olduğu yönündedir.

Anahtar Kelimeler: Mekân kimliği, tüketim kimliği, sosyal kimlik, tematik analiz, güvenlikli konutlar,

\begin{abstract}
In this study, we focused on the question of what kinds of new arrangements that gated residential places with private security that were introduced into daily life with a discourse of "not only buying a house but a lifestyle" caused in daily lives of their residents. We have offered explanations about these residents' life in their houses, their comments based on comparisons they made in terms of people living outside these closed places, behaviours of consumption and their construction of new identities concerning social context and place using a social psychological approach. Fort this study, we have carried out focus group interviews with 7 married couples who were residents of such places located in different districts of Istanbul. We have analyzed the data in focus group interviews using the method of categorical thematic analysis utilizing the MAXQDA 2018 software.

We observed that the participants regarded their life in providing such places as a consumer behaviour ensuring an indispensable necessity. We determined that along with the perception of living in these places as an indispensable necessity, the residents experienced anxiety and fear of raising children in a city coupled with emotions of feeling valuable. The security conditions, physical conditions and architectural characteristics providing a closed space separated from outside with high walls of these places brought forth feelings of being safe and privileged along with feelings of being isolated and imprisoned for the participants. Our main claim is that these residential places with their offers of distancing the residents from various negative feelings cause new arrangements and changes in the daily lives of their residents because of establishing specific and new norms.
\end{abstract}

Keywords: Place identity, consumption identity, social identity, thematic analysis, gated residential places.

\footnotetext{
${ }^{1}$ Arş.Gör, İstanbul Üniversitesi, yakup.azak@istanbul.edu.tr, Orcid: 0000-0002-2720-7744

${ }^{2}$ Dr.Öğr. Üyesi, İstanbul Üniversitesi, Edebiyat Fakültesi, Psikoloji Bölümü, tekdemir@istanbul.edu.tr, Orcid: 0000-0002-5988-4176
}

Makale Türü: Araştırma Makalesi - Geliş Tarihi: 27/09/2019 - Kabul Tarihi: 15/12/2020 


\section{GIIRIS}

Güvenlikli ve yüksek duvarlı kapalı konutlar, (bundan sonra GYDK Konutlar kısaltma ifadesi kullanılacaktır) gelişmekte olan ülkelerde sayıları giderek artmakta olan yapılardır (Ehwi, Morrison \& Tyler, 2019). Çalışmamızda, bu fenomeni, ihtiyaca yönelik küresel bir tüketim pratiği olarak ele almak yerine yerel ve bağlama özgü faktörlere odaklanarak açıklamayı tercih ettik. İstanbul ili özelinde şehrin farklı ilçelerinde inşa edilmiş GYDK Konutları sakinlerinin bu yeni mekanlarda yaşam deneyimlerini nasıl anlamlandırdıklarına odaklandık. Türkiye'de orta ve üst gelir seviyesindeki çalışan aileler, sosyal düzeylerine uygun yaşam tarzı bulma motivasyonuyla özellikle seksenlerden itibaren artan sayılarda "modern yaşam alanları" arayışına girmişlerdir (Bali, 2002, s. 122). Bu yaşam alanlarında dikkat çekici özellik mekânların sadece birer konut olmakla kalmama iddiası ile sunulmasıdır. Konutların pazarlanması sürecinde reklamlar elle tutulamayan ve gözle görülmeyen ancak ayrıcalıklı olduğu varsayılan bir yaşam tarzı da satıyor olma iddiasına sahiptir. Etrafı yüksek duvarlarla çevrili, kapıları herkese açık olmayan seçici geçirgen özellikte mimari özelliklere ve teknolojiye, güvenlik görevlilerine sahip, alışveriş mağazalarının yakınlarında nezih ve seçkin olarak işaretlenmektedir. Güvenlik elemanlı ve kapalı konut yaşam alanları olarak isimlendirilen mekânlarda boş zamanı değerlendirmek için fitness alanı, havuz, lokanta ve kafe gibi somut olanaklar sağlanarak tüketicilere eski geleneksel yaşamlarından farklı bir yaşam kurma ve sürdürme seçenekleri sunulmaktadır. Bu yeni yaşam alanlarının sakinleri olmak, yüksek meblağlarda tüketim pratiğini insanların ekonomik harcamalarına dahil etmelerini gerektirmektedir. Bu tüketim pratiğiyle konut sakinlerinin yaşamlarına neleri dahil ettikleri ve gündelik yaşam pratiklerindeki değişimi nasıl anlamlandırdıkları bu çalışmanın genel araştırma sorusu olarak ele alınmıştır.

Tüketim kültürünün tarihsel sürecine bakıldığında tüketim kültürünün doğduğu ülkelerde 1950'lerde iş gücünün artması, düzenli ve sürekli maaş alabilme imkânının doğması, tüketimde hızlı artışlara sebep olmuştur (Featherstone, 1996, s. 77). Zamanla sınıf içerikleri, tüketim ve satın alma gücü ile doldurulmuştur. Bu aşamada medya, ideal yaşam tarzları sunarak tüketimle sınıflar arası sosyal hareketliliğin sınırlarının kalkacağı vaatleriyle birlikte sınıflar arası geçişlerin yol haritası artık tüketimle çizilmeye başlanmıştır. Tüketim kültürünün günlük yaşam içinde egemen hale gelmesiyle birlikte sunulan içeriğinde kişisel özgürlük alanları, konfor ve kolaylıklar olan yaşam tarzları arzulanır hale getirilmiştir (Turnock, 2007, s. 43). Türkiye'de ise tüketim kültürüne geçiş, 1980'lerle birlikte görünür hale gelmiştir. İnsanlar artık üretim yerine tüketim pratikleri ve nesneler ile kimliklerini kurmaya başlamıştır (Orçan, 2004, s. 242).

\section{Sosyal kimlikler, tüketim ve mekân kimlikleri}

Bocock'a (1997) göre tüketim, insanların "kim olduklarını, kim olmak istedikleriyle ilgili hassasiyetlerini korumalarını" sağlayan yöntemleri de etkilemektedir. Aynı zamanda kimlik sahibi olma duygusunun gelişimini etkileyen yapılarla da içi içe geçmektedir. $\mathrm{Bu}$ nedenle tüketim, ekonomik olduğu kadar toplumsal, sosyal psikolojik ve kültürel bir olgudur. Kimliğin, bireyden çıkıp grup aidiyetleri bağlamında tanımlanmasına bağlı olarak sosyal kimliklerden söz edilebilir. Sosyal kimlik, kişinin kendini yakın gördüğü bir grup bağlamında kim olduğuna ve bu grubun dışında kalanlara dair değerlendirmeleridir. Bu şekilde bireyler kendilerini bir grup terminolojisi içinde tanımlamaya başlayarak grup özdeşimleri devreye girmektedir (Reicher, Spears \& Postmes, 1995, s. 163). Grup tanımlarıla, diğer gruplarla sosyal karşılaştırmalar yapılır hale gelir (Turner, 1986, s. 74; Hogg \& Abrams, 1992, s.14). Eğer kişi kendini, grubu içinde pozitif bir sosyal kimlikle algıliyor ise kendi grubunu kayırmaya ve diğer grubu olumsuzluklarla değerlendirmeye başlamaktadır (Tajfel \& Forgas, 1981, s. 114). 
Tüketim kültürü, modernleşme gibi toplumsal yapılanma şekilleri, kimlik oluşumlarını etkilemektedir. Modernleşme sonrasının ürünü olan yaşam tarzı olgusunun içinin tüketim pratikleri ile doldurulması ile kimlikler "giyinilen ve sürekli değiştirilen bir yapıya" sahip hale gelmiştir (Bauman, 2005, s. 183). Bu postmodern kimlik anlayışı içinde yükselen kimliklerden biri de mekân kimliğidir. Mekân kimliği üzerine çalışmalar bir mekân ile o mekânda yaşayan insanlar arasındaki ilişkiyle ilgilidir. İnsanların kimliğinde yaşadıkları yer kendileri için önem arz etmektedir. Sosyal psikolojide kimlik alanında yapılan çalışmalarda "biz kimiz" sorularının "biz nereye aitiz" soruları ile olan ilişkisi çoğunlukla göz ard1 edilmiştir. Fakat sosyal psikologlar tarafından devamlı araştırılan birçok sosyal kategori (toplum, etnisite, kent, ulus devlet, cemaat) kavramları yer (mekân) ile önemli derecede ilişkilidir. Mekân kimliğinin insanın güvenlik duygusu ve kontrol ihtiyacının karşılanması, grup ve topluluk düzeyinde kimlikler oluşturma ihtiyacının giderilmesi gibi fonksiyonları vardır (Taylor, 2005, s. 250). Mekân kimliğini etkileyen kavramlardan biri de alansallıktır (territoriality).

\section{Alansallık}

Bir grubun ya da kişinin sergilediği ve özel bir alanın sahiplenildiğine dair algıyı kuran davranışlar bütünüdür. Bu alansallık, grubun ya da bireyin kimliğini inşa etmesine, korumasına ve desteklemesine yardımcı olmaktadır (Göregenli, 2010, s. 106). Ev sahibi ülke vatandaşlarının göçmenlere yönelik tepkilerinin içeriğinde ülke üzerinde bir nevi alansallık algısı yer almaktadır. Bu alansallık ise yine kolektif sahiplik beraber gelişen gruplararası seviyede davranış düzenlemesidir. Örneğin Türkiye'de insanların bir kısmının ülke üzerinde kolektif sahipliğe Suriyelileri dahil etmiyor oluşunda bu alansallıkla gelişen kolektif sahiplik algısı da bulunmaktadır (Azak, 2020, basım aşamasında).

Mekânın alansallığı, orada doğmuş olmakla, orada geçirilen zamanla ve aile bağlarının mekânla olan ilişkisine göre değişkenlik göstermektedir. Bu çalışmada alansallığın tüketim pratiği olarak güvenlik elemanlı ve kapalı konutlar bağlamında sunulan yaşam tarzıyla ilişkisine de odaklanılması amaçlanmıştır. Yaşanılan konut yaşam alanı üzerine alansallık bağlamında çalışma bulunmamaktadır. Fakat yuvanın/evin anlamı üzerine yapılan çalışmalarda katılımcıların, anne, baba ve aile hariç başkaları ile paylaşılan evi, yuva olarak belirtmediklerine işaret etmektedir (Sixsmith, 1986, s. 283). Yuva, düzen sağlayan, mekânsal yaşantımıza ve davranışımıza yön veren bir araç, "bir aynileşme objesi, bütünleşme ve mekânsal ilişki sağlayan bir ilişki kurma biçimi” olarak ta ele alınabilmektedir. Yaşanılan ev, bir aileye ve akrabaya aidiyet, bireye sosyo-ekonomik mevki duygusu da verebilmektedir (Dovey, 1985, s. 34). Ev, oda, yatak odası, bireyin ya da grubun o alana sahip olduğunu hissettiren yerlerdir. Bu alanlarda kontrolü sağlamak birey ya da grup için önemlidir. Dışarıdan müdahalenin olması, büyük tepkiyle karşılanır. Evler, mahremiyet algısının en güçlü olduğu alanlardır. Bunun yanında mülkiyet ve kullanım haklarının da yasalarla da korunduğu en temel yer ve birincil alansallıklardır (Göregenli, 2010, s.107).

İkincil alansallık, kişiler için daha az önemlidir. Örneğin okuldaki sıra, sürekli gidilen kafe, sürekli alışveriş yapılan dükkânlar ikincil alansallık taşıyan mekânlardır. Genelde bu mekânlar daha fazla kullanıcıyla paylaşılan yerlerdir. Bu tip alanlarda kontrol tam olarak sağlanamamaktadır. Çalışmalar, araştırmamız için mekân ve özellikleri ile yaşam tarzı ilişkisinin incelenmesi gerekli hale getirmektedir.

\section{Yaşam tarzı, güvenlikli ve yüksek duvarlı kapalı konutlar}

Başta İstanbul olmak üzere birçok şehirde toplu halde konumlandırılmış, güvenlikli ve yüksek duvarlı kapalı konutlar (GYDK Konutlar) şehir merkezinden uzakta yeni merkezler anlamına gelen uydu kentler inşa edilmeye başlanmıştır (Öncü, 1999, s. 27). Orta sınıfın kendini alt sınıflardan ayırma stratejilerinden biri de ev sahibi olma çabasıdır. Bu çabanın 
nedeni, bireylerin kim olmak istediği ya da nasıl görünmek istediği ilgili endişeleridir. $\mathrm{Bu}$ endişe tüketimle beraber anılan bir "yaşam tarzı" inşa etmiştir (Chaney, 1999, s. 15). Bu yaşam tarzının belirlediği şekilde diğer insanlarla ilişki biçimleri kurulması modern bir söylem olan "yaşam tarzı" olgusunu, çalışmanın odak noktası haline getirmiştir (Douglas \& Isherwood, 1999, s. 8).

Bilgin'nin (1991) kendi ifadeleri ile farklı sosyokültürel özelliklerdeki gruplar, sonsuz denilebilecek tüketim eşyaları evreni içerisindedirler (s. 83). Bu doğrultuda birey ve gruplar gerekli gördüğü eşyayı almakta, kullanmakta ve atmaktadır. Burada aktif olan tüketici bireyin, Bilgin'in işaret ettiği kadar aktif olmadığı durumlar da söz konusu olabilmektedir. Tüketimin ana dinamiği ihtiyaçtır. Fakat ihtiyaç, her zaman eşya ile kurulan doğrudan bir ilişki değildir. İhtiyaçlar, bir sistem olarak üretilmektedir ve dolayısıyla manipüle edilebilir. Araba, elektrikli tıraş makinesi, tek başına anlam taşımaz. Bu ürünlerin sosyal hayatta algılanışı, sınıfsal yeri ile anlam taşır (Baudrillard, 1997, s.76). Bu tarz tüketim ürünleri, bir yaşam tarzının gelenek ve alışkanlıkları üzerinden tüketim alışkanlıkları yerine, yaşam tarzının kendisi edinilecek ve tüketilecek ürünlere ilişkin bir model haline gelmiştir. Ürünler, giysiler, arabalar, konutlar "bir yaşam tarzı oluşturmak için bir araya getirilir". Eşyaların anlamı artık başka bir eşya ile anlam kazanmaktadır. Eşya bir sistemin içerisinde yer alır ve bu sistemin, "yaşam tarzını ve ihtiyaçları belirleme" durumu söz konusudur (Baudrillard, 2004, s.32). Nasıl görünmek ve kim olarak görünmek istediğimiz, kim olduğumuzla ilişkili hale gelmiş ve kim olduğumuz da tüketim kaynaklarını kullanış şeklimiz aracılığı ile anlaşılır olmuştur (Chaney, 1999, s.37).

GYDK Konutlarda spor aktiviteleri, yüzme havuzları işlevsel değerleri ile değil yaşam tarzına dair göstergesel mesajlar taşıması sebebiyle tüketim nesneleri haline gelir. Yani konut projelerinde yer alan aktivite alanları (yüzme havuzu, spor salonu, vb.) işlevsellik taklidi (simulacra functionality) yaparak kullanıma dair bir ihtiyaç olmaktan ziyade, sosyal farklılaştırıcı rolündedir (Baudrillard, 2004, s.79). Eşya fiziksel işlevi dışında da özelliklere sahip olmaktadır. "Herkes eşyaları ile yargılandığının farkındadır ve bu farkındalığı yadsıyabilir ama bu yargılamalara göre davranmaya devam etmektedir." (Bilgin, 1991, s.364). Ev, "ihtiyaç olmaktan öte ve orta sınıf kültürünü yansıtan" modern zamanlara ait bir tüketim ürünü haline gelmiştir (Öncü, 2005, s. 102). 2020 yılı Covid-19 pandemi süreciyle birlikte mekânsal ihtiyaç kavramı da değişim göstermiştir. Doğal hayat, açık alan ve sağlıklı arasında kurulan doğrudan ilişkiler gözlemlenmeye başlanmıştır (Tanhan, 2020). Fakat pandemiyle beraber bu durum köyde kurulan yaşamda duyulan ihtiyaçların şehirde sahip olunanlar üzerinden kurulduğunu da göstermektedir. Köyde çevre ve düzenlemede altyap1, internet ihtiyacı daha görünür ve karşılanması beklenen ihtiyaçlar haline gelmiştir. Binaların mimari yapısında bolca ve doğal yollarla hava sirkülasyonunun sağlanması şeklinde yeni ihtiyaçlar ortaya çıkmıştır (Tanhan, 2020)

Çalışmanın kuramsal çerçevesi, sınıfsal bağlamda oluşan sosyal kimliklerin tüketim pratikleriyle ortaya koyulur hale gelmesi ve bu tüketim pratiklerinin de yaşanacak yer satın alma söz konusu olduğunda yeni alansallık ve dolayısıyla yaşam tarzı tanımlamalarını beraberinde getiriyor olması temeline dayanmaktadır. Yeni sınıfsal bağlamda oluşan sosyal kimlik, mekânın bireyler tarafından sahiplenilmesi sürecini tetiklemekte ve tüketimi bir ihtiyaç haline getirmektedir. Dolayısıyla da bu tüketim yeni bir mekân kimliği ile somutlaştırılmakta ve bu somutlaştırma sürecinde yeni yaşam tarzına ilişkin normların algılanması, mekân öncesi yaşamla karşılaştırılması, nihayetinde de yeni mekanlarda alansallık algısının oluşmasına zemin oluşturmaktadır.

$\mathrm{Bu}$ çalışma, GYDK Konutlarda yaşayanların tüketim pratiğiyle gelen yaşam tarzını kendi yaşam deneyimleri üzerinden nasıl anlamlandırdıkları ve mekân deneyimleriyle ortaya çıkan bu yaşam tarzı olgusunu düzenleyen araçların neler olduğu sorularına cevap bulma amacını taşımaktadır. 


\section{YÖNTEM}

\section{Katılımcilar}

Araştırma ekibi olarak Robinson'un (2014) önerdiği gibi araştırmanın evreninin belli başlı kaynaklarda homojen olmasına önem verdik. Tarihsel ve coğrafi kaynaklı homojenlik için GYDK konut yaşam alanlarının İstanbul ilinde (Bağcılar, Kağıthane, Gaziosmanpaşa, Kurtköy, Çekmeköy ve Güneşli) 2020 yılı itibariyle son 15 yıl içinde inşa edilmiş olmasına dikkat ettik. Mekânsal kaynaklı homojenlik için güvenlik önlemlerinin (güvenlik elemanları ve güvenlik kamera sistemleri) olduğu kapalı duvarlarla korunan, içinde ortak kullanıma açık spor salonları, otoparkları ve yüzme havuzu gibi sosyal aktivite alanları ile mimari özelliklerde ortaklaşan konut yaşayanları araştırmaya dahil ettik. Demografi kaynaklı homojenlik kendilerini orta veya üst gelire sahip olarak tanımlayan, üniversite lisans veya lisansüstü eğitime sahip olma sınırlığı getirdik. Bu homojenlik özelliklerine sahip yedi evli çift araştırmanın örneklemini oluşturmuştur.

25-35 yaş aralığında 4 evli çift ve 35-50 yaş aralığında 3 evli çift olmak üzere toplam 7 evli çifte (14 kişiye), araştırmaya katılan çiftlerin araştırma ekibini diğer çiftlere yönlendirmesi sonucu kartopu örneklem yöntemiyle ulaştık. 5 katılımcı çift 2013 ile 2015 yılları arasında ev sahibi olmuştur. İki katılımcı çift ise kiracı olarak 5 yıldır GYDK Konutlarda yaşamaktadır.

Katılımcı çiftlerin politik duruşları ve dini yönelimleri her bir çiftin kendi aralarında birbirine yakın bulunmuştur. Sadece ilk evli çiftte erkek katılımcı politik görüşünü Liberal Demokrat olarak tarif ederken kadın katılımcı Ulusalcı Kemalist olarak tarif etmiştir (bkz. Tablo 1).

Tablo 1. Katılımcı Bilgileri

\begin{tabular}{llllccc}
\hline Katılımcılar & $\begin{array}{l}\text { Çocuk } \\
\text { sayısı }\end{array}$ & $\begin{array}{l}\text { Konut } \\
\text { sahibi }\end{array}$ & $\begin{array}{l}\text { Kredi } \\
\text { kullanımı }\end{array}$ & $\begin{array}{l}\text { Ailenin geliı } \\
\text { seviyesi }\end{array}$ & $\begin{array}{l}\text { Konut } \\
\text { ödemeleri }\end{array}$ & kredi \\
\hline Erkek 1 & 1 & Evet & Var & Orta & Var & Liberal Demokrat \\
\hline Kadın 1 & 1 & Evet & Yok & Orta & Var & Kemalist Ulusalcı \\
\hline Erkek 2 & 2 & Evet & Yok & Yüksek & Yok & Kemalist Ulusalcı \\
\hline Kadın 2 & 2 & Evet & Yok & Yüksek & Yok & Kemalist Ulusalc1 \\
\hline Erkek 3 & 0 & Evet & Var & Yüksek & Var & Kemalist Ulusalc1 \\
\hline Kadın 3 & 0 & Evet & Var & Yüksek & Var & Kemalist Ulusalc1 \\
\hline Erkek 4 & 0 & Hayır & Var & Orta & Var & Muhafazakâr Demokrat \\
\hline Kadın 4 & 0 & Hayır & Var & Orta & Var & Muhafazakâr Demokrat \\
\hline Erkek 5 & 3 & Evet & Var & Yüksek & Var & Liberal Demokrat \\
\hline Kadın 5 & 3 & Evet & Var & Yüksek & Var & Liberal Demokrat \\
\hline Erkek 6 & 1 & Hayır & Var & Orta & Yok & Kemalist Ulusalc1 \\
\hline Kadın 6 & 1 & Hayır & Var & Orta & Yok & Kemalist Ulusalc1 \\
\hline Erkek 7 & 1 & Hayır & Yok & Orta & Yok & Liberal Demokrat \\
\hline Kadın 7 & 1 & Hayır & Yok & Orta & Yok & Liberal Demokrat \\
\hline
\end{tabular}

\section{Görüşmeler ve analizler}

Görüşmeler öncesinde katılımcılara kendilerinden elde edilecek verinin ne amaçla kullanılacağını, çalışma için tercih edilme nedenlerini, veri toplama gereci olarak ses kayıt işleyişini içeren bilgi-onam formu verilmiş ve çalışma için onayları alınmıştır. 2017 yılı Nisan-Aralık ayları arasında gerçekleşen ve 40 ila 90 dakika arasında sürelerde değişen 7 odak görüşme sonucu veriler elde edilmiştir. Görüşmelerde evli çiftlerin her biriyle kendi yaşadıkları konutlarda eşlerin birbirleriyle etkileşimleri olacak şekilde görüşme sorularına yönelik beraber inşa ettikleri düşünce ve duyguları elde edebilmek için odak görüşme yöntemini tercih ettik.

Görüşme sorularının belirlenmesinde ilk olarak çalışmanın araştırma sorusunu ve konut reklamları üzerine yapılan analizleri temel alarak yarı yapılandırılmış ilk taslak 
görüşme sorularını oluşturduk. İlk pilot görüşme sonrası görüşme soruları üzerindeki ilk düzenlemelerimizi yaptık. Ardından yapılan ikinci pilot görüşme sonrası araştırma ekibinin görüş birliğiyle görüşme sorularına son halini verdik (Sorular Ek 2'de sunulmuştur). Odak görüşme sürecini iki bölüm halinde gerçekleştirdik. İlk bölümde katılımcılara güvenlikle konutları satın alma ya da yaşamaya karar verme süreçleri hakkında ve bu konutlarda yaşadıkları süre ve sosyo-demografik bilgilerin edinilebileceği bilgi formları verdik. İkinci bölümde ise katılımcıların kendi konut yaşam alanlarına dair algılarını (GYDK konutlarda yaşamı tercih nedenleri, uyum süreçleri, site içi ve dışında yaşayan diğer insanlar hakkında mekân bağlamında anlamlandırmaları) içeren sorular üzerinden görüşmeleri sürdürdük. Tüm görüşmelerden elde edilen verileri yazı dökümü halinde analize hazır hale getirdik.

Verilerin analizi için tematik analiz yöntemini tercih ettik. Verileri açı kodlama (tümevarımsal) bir yöntemle inceledik. Tematik analiz yöntemi, veri içindeki paternleri (temaları) tanımlama, analiz etme ve raporlama yöntemidir (Braun \& Clarke, 2008). Analiz adımları için Frith ve Gleeson'ın (2004) erkeklerin vücut imajları yönetimi üzerine tümevarımsal tematik analiz ve Erlingsson ve Brysiewicz'ın (2017) içerik analizi rehberi adlı çalışmalarındaki analiz adımları takip ettik. Bu adımlar takip edilerek, ilk aşamada görüşme verileri görüşmenin bütünü hakkında genel bir fikir sahibi olabilmek adına tekrar tekrar okuduk. Verilerin cümleler üzerinden anlam birimleri şeklinde kodlanmasının biz kodlayıcılar için daha uygun olacağına karar verdik. Analize, anlam birimleri, anlamın yoğunluğunun etiketlenmesi yani kodlanma işlemiyle devam ettik. Birden fazla araştırmacıyla yürütülen tümevarımsal nitel içerik analizlerinde güvenirlik (trustworthiness) için analizden sorumlu bir araştırmacının tüm analiz ve kategorilendirme süreçlerinin diğer araştırmacı tarafından takip edilmesi önerisini (Elo ve ark., 2014) dikkate alacak şekilde görev paylaşımı yaptık. Analizlerde MAXQDA 2018 bilgisayar yazılımı kullanılmıştır. Yazılımın sunduğu otomatik kodlamaları analize dahil etmedik. Bu sebeple çalışmada kodlayıcılar arası anlaşma düzeyi (kodlayıcılar arası güvenirlik) inceledik (Neuendorf, 2017 s.154). İlk görüşme verileri araştırma süreci hakkında bilgi sahibi iki kodlayıcı olarak farklı zaman ve ortamlarda kodlamalar yaptık. Görüşme ifadelerinin ele alındığı kodlamalara dair kodlayıcılar arası anlaşma düzeyi Tablo 2'de verilmiştir. Krippendorf (2004)'un kullandığ 1 anlaşma düzeyleri çalışmada güvenirlik kriteri olarak belirledik. Bu şekilde anlaşma düzeyi .60'tan küçük ise kodlama analize dahil edilmemiştir. .60-80 arası anlaşma düzeylerindeki ifadeler tarafımızca tekrar gözden geçirilmiştir. .80 ve üzeri anlaşma düzeyi uygun anlaşma kıstası olarak kabul edilmiştir.

Tablo 2. İlk görüşme verilerinin kodlanması sonucu iki kodlayıcı arası anlaşma düzeyleri

\begin{tabular}{lcccc}
\hline Kodlar & İlişkili kodlama İlişkisiz & Toplam & $\begin{array}{c}\text { Anlaşma } \\
\text { Dülama }\end{array}$ \\
\hline Yırtıcı çocuk yok & 2 & 0 & 2 & 1 \\
\hline Whatsapp grupları & 2 & 0 & 2 & 1 \\
\hline Şımarık istekleri olan kapalılar & 2 & 1 & 3 & .67 \\
\hline Sosyalleşmede zamanın boşa gitmesi & 4 & 1 & 5 & .80 \\
\hline Sosyalleşmeler & 2 & 0 & 2 & 1 \\
\hline Sokağa göre çocuk bakmak iyi & 2 & 1 & 3 & .67 \\
\hline Sohbete çağrılmamayla ilişkiler bozulması & 2 & 0 & 2 & 1 \\
\hline Site içi yardımlaşma & 2 & 0 & 2 & 1 \\
\hline Site aktiviteleri & 2 & 0 & 2 & 1 \\
\hline Sicak insanlar & 4 & 0 & 4 & .75 \\
\hline Samimileşmeyi sağlayanlar & 6 & 2 & 8 & .33 \\
\hline Samimileşme isteği & 2 & 4 & 6 & 1 \\
\hline Ramazan buluşmaları & 2 & 0 & 2 & 1 \\
\hline Otopark hakkı & 2 & 0 & 2 & 1 \\
\hline
\end{tabular}




\begin{tabular}{lllll} 
Mahalle anlayışı & 2 & 0 & 2 & 1 \\
\hline Kuralların utandırması & 4 & 0 & 4 & 1 \\
\hline Kavgaların çımama nedeni & 2 & 0 & 2 & 1 \\
\hline Karşılaşmalar & 2 & 0 & 2 & 1 \\
\hline İzinle giren misafir & 2 & 1 & 3 & .67 \\
\hline İş yapmayı engelleyen sosyalleşme & 6 & 0 & 6 & 1 \\
\hline Havuz için izin verilmeyen misafir & 2 & 3 & 5 & .40 \\
\hline Hastane ziyaretleri & 0 & 2 & 2 & 0 \\
\hline Güvenlik uyarısı & 2 & 0 & 2 & 1 \\
\hline Gürültü üzerinden şikâyet & 2 & 0 & 2 & 1 \\
\hline Futbol oynama & 2 & 0 & 2 & 1 \\
\hline Eşi aracıllğı sosyalleşme & 2 & 0 & 2 & 1 \\
\hline Eğitimli ailelerin çocukları & 2 & 0 & 2 & 0 \\
\hline Daha büyük site daha az baskı & 0 & 2 & 2 & 1 \\
\hline Çocuklara bakan başkalarının olması & 2 & 0 & 2 & 1 \\
\hline Çay kahvaltı sohbetler & 2 & 0 & 2 & .50 \\
\hline Çardak buluşmaları & 2 & 2 & 4 & 1 \\
\hline Beraber oynayan çocuklar & 2 & 0 & 2 & 1 \\
\hline Asansörden inme & 4 & 0 & 4 & 1 \\
\hline Alkolle geliyor olmam gözükmesin & 4 & 0 & 4 & .75 \\
\hline Toplam & 82 & 28 & 110 & \\
\hline
\end{tabular}

Elde edilen anlaşma düzeyi yüksek kodların belirlenmesi, kodlayıcıların kendi aralarında sonradan inceleyecekleri veriler için bir yol haritası oluşturacak kod kitabına sahip olmamızı sağlamıştır. Böylelikle araştırma konusu dışındaki kodlamaların belirlenmesi kolaylaşmıştır (Ek 1'de muhtelif kodlamalara ulaşılabilir). İçerik ve bağlam olarak birbiriyle ilişkili kodları aynı kategoriler altında bir araya getirdik. Kategorileri oluşturulurken verideki benzerlikler veya farklılıklara odaklandık. Kategorilerin çeşitliliğinde ise araştırma soruları yönlendirici olmuştur. Tematik bir analiz türünde kategori oluşturulmasının tercih etmemizin sebebi ise Elo ve Kyngäs'1n (2008) önerdiği gibi verideki olguyu daha somut şekilde tanımlamayı amaçlamış olmamızdır. Verilerin içeriğini tanımlayan kategoriler üzerinden temaların belirlenmesi aşamasına geçtik. Temalar da ise birden fazla kategori içeriğindeki soyut ve gizil anlamları vurgulanmayı amaçladık. Kategorilerin, içerikteki kim, ne, ne zaman, nerede sorularına cevap oluşturabilmesini; temaların ise niçin, nasıl, hangi yolla ve ne anlamda sorularına yanıtlar oluşturabilmesine dikkat ettik (Erlingsson \& Brysiewicz, 2017). Oluşturulan taslak temalardan yeterince veriyle desteklenemeyenlerin diğer temalarla olan ilişkileri gözden geçirdik. Nihai olarak temaların kendi içlerinde homojen diğer temalarla heterojen bir yapıda olmasına (Braun \& Clarke, 2006: 91) dikkat ederek verilerin analizinden çalışmanın amacına uygun 3 tema altında toplam 11 kategori elde ettik (Bkz. Ek1).

\section{BULGULAR}

Yaptığımız nitel analiz sonucunda belirlemiş olduğumuz temaları en iyi temsil eden alıntılara yer verdik. Kadın katılımcıları, Kadın 1...Kadın 7; erkek katılımcıları ise Erkek 3 ...Erkek 6 şeklinde sadece cinsiyetleri belli olacak şekilde anonimleştirmeyi tercih ettik.

\section{Keyfi değil zorunlu bir ihtiyaç olan yaşam alanı}

Konut yaşam alanın sunduğu yaşam tarzı konut sakini katılımcılar için tercihin ötesinde zorunluluk olarak algılanmaktadır. Bu zorunluluk derecesindeki ihtiyaç algısının, konut yaşam alanının İstanbul'un hangi bölgesinde bulunduğuyla ilişkili olduğunu vurgulayan katılımc1, bazı bölgelerin kendine has güvenlikle ilişkili bir kültür yapısı olduğunu 
belirtmiştir. Aşağıda sunulan alıntıda görüldüğü gibi GYDK konutlarda yaşam zorunluluğu, çevrenin sosyokültürel yapısı ile ilişkilendirilmiştir:

"Erkek 2: işte Băgcllar, Güneşli, Güngören buralar ĕger ki Cadde de otursam mümkün değil bu rezidansta oturmak istemezdim. Ben oranın eski yaşantısı benim için eski Istanbul beyefendileri falandır. Cadde de site var ama daha çok evler var. Orada şehrin zaten kendi güvenliği var kültür olarak. Ayrıca bir siteye pek ihtiyaç yok"

Güvenlik boyutu, yaşanılan muhite ve güvenlik elemanlı ve kapalı konut yaşam alanları dışında yaşayanlara (dışardakilere) atfedilen tekinsizlik işaretlemesi, çocuk yetiştirme pratiklerine eşlik eden endişe ve korkularında ortaya çıkabilmektedir. Katılımcıların çocukların uzak durması gereken kişileri ve mekânları işaretleyerek kendi yaşam alanlarını bir zorunluluk algısı içinde görmelerinde etkili olmaktadır. Bu değerlendirmeye bir örnek aşağıdaki alıntıda yer almaktadır.

"Kadın 6: Dediğim gibi mevki de oturan daha böyle şey çok çarşaflı, kapalı kadın var. Adamı göremiyorsun ne olduğunu anlayamadiğın insanlar var yani ve dediğim gibi halk otobüsleri çok var ve artık Çekmeköyde de oluyor çocuk kaçırma olayları."

Katılımcılar, dini kimliği işaretleyen giyim tarzını çocukların kaçırılması üzerinden tekinsizlikle işaretlemektedir. $\mathrm{Bu}$ durumun oluşturduğu endişe güvenlik elemanlı ve kapalı konut yaşam alanlarını katılımcı için zorunlu hale getirmektedir. Yaşam alanlarının işlevsel bir özelliği olan otopark imkânı, aşağıdaki alıntıda görüldüğü üzere "şehirde insanca yaşamayl” işaretleyen bir yaşam tarzının en önemli şartına taşınmıştır.

"Erkek 3: kapalı otopark bir kere insan olmanın yani insanca bir şehirde yaşamanın birincil şartı"

Otopark gibi ekonomik seviyeyle elde edilen birtakım imkânların kimliklerle gelen sembolik ihtiyaçları da karşılayabildiğine dair algı kadın kimliğinin işaretlendiği yaşam tarzı pratiklerinde de ortaya çıkmaktadır. GYDK Konutları yaşam alanları dışı "arka mahalleler", katılımcı tarafından kadın kimliği üzerinden yaşanılan rahatsızlıklarla ilişkilendirilirken, konut yaşam alanı ise sunduğu imkânlarla -havuz- yine kadın kimliğiyle de rahatlıkla performe edilebilen pratikleri ve kolaylıkları destekleyen yaşam tarzıyla ilişkilendirilmektedir.

"Kadın 6: Ben sadece insanların bön bön bakmadı̆̆ böyle şey olur ya siteden çıktığın an rahat değilsin bir kadın olarak yani atıyorum arka mahalleler falan diyorum ya ben havuzdan çıkıp evime geliyorum öyle ve çok rahatız"

\section{Güvenliği sağlarken yaşam pratiklerini de düzenleyen güvenlik işleyişleri}

Güvenlik elemanlı ve kapalı konutlarda güvenlik işleyişi, konut yaşam alanına giriş çıkışları kontrol altında tutma adına bir takım güvenlik işleyişlerini devreye sokmaktadır. Bu güvenlik uygulamaları dışardan geleni kim olduğu ve kime geldiği üzerinden tanımlama amacı olması dışında konut yaşam alanı içinde konut sakinlerinin davranışlarını onlara mekân üzerinde kontrol yetkisi verilerek, dişardan gelen misafirleri ise kontrol edilen ve güvenilir olanı işaretleyebilme konusunda davranışlarını düzenleyici role de sahip olduğu gözlemlenmiştir.

"Kadın 1: dışardan biri geldiğinde güvenlikle karşılaşıyorlar kapıdan aranıyorlar. Biz müsahade edince giriyorlar"

İşleyiş sürecinde ana kapıdan geçildikten sonra dairenin bulunduğu binaya giriş için "şifre işlemiyle" devam edilmektedir. Katılımcılar, alıntıdaki ifadeye benzer biçimde bu süreçte dişardan gelenin bu sürece uyumunun zorlu bir süreç olduğunu ifade etmektedir. 
"Erkek 1: blok kapısina geldiklerinde tekrar şifreyle araması gerekiyor. Aramakta zorlanıyorlar genelde... (gülüşmeler)... biz burdan karşıllyoruz"

Dışardan gelen kişilerle konut yaşamı alanı içinde yaşanan deneyimler mekânın kendi sosyal ilişki normlarının katılımcılar için de en çok görünür hale geldiği zamanlar olduğu iddia edilebilir.

"Kadın 1: misafir edemiyorum mesela. Üzülüyoruz babası geliyor giremiyor çünkü parmak okuma sistemi var. Fitnis için kart, sauna havuz ve buhar odast için parmak okuma sistemi var... Kullanamıyor giremezsin diyorum utanıyorum"

Yaşam alanının havuz, otopark, spor salonu vb. imkânları sadece konut sakinleri için sunuyor olması, geleneksel misafir ağırlama ritüelleri ile yeni mekân normlarının çatışmasına neden olabilmektedir. Misafirlerin arabalarının konut alanına alınmaması, aktivite alanlarının kullanımına izin verilmemesi konut sakinlerinin utanma gibi olumsuz sosyal duygular yaşamalarına neden olabilmektedir. Katılımcıların bu çatışma durumlarına karşı, aşağıdaki örnek alıntıda görüldüğü gibi çözüm aradıkları gözlemlenmektedir.

"Erkek 2: açıkçası öyle güvenlikten geçmelerinden ise ben bir aşağıya inip hani karşılayıp misafirlerim diyip geçirmek isterim”

Konut sakini katılımcı mekânın misafir ağırlama işleyişine dahil ettiği yeni sosyal kurallara karşı kapıda karşılama eylemiyle geleneksel misafir ağırlama işleyişini devreye sokmuştur. $\mathrm{Bu}$ durum bir bakıma iki farklı normatif davranışın çakışması olarak yorumlanabilir. Bir başka alıntıda katılımcının geleneksel mahalle anlayışı olarak işaretlediği "balkona çamaşır asılamaması" gündelik hayat pratiğini kendi evinde yapamıyor olması ev hayatına konut yaşam alanının normatif davranışına müdahale olarak algılanmakta ve durum katılımcının, örnek alıntıda görüldüğü gibi gündelik davranışlarda da düzenlemeye gitmesiyle neticelenmektedir.

"Kadın 5: ben mahalle hayatını seviyorum o yaşamları niye seviyorum mesela dışarı çamaşır askısılla çamaşır asmak istesen hani güvenlik beni arayabiliyor. Çamaşır astınız diye evde kurutma makinesi var ama her şeyi kurutamıyorum. Burast yaşadiğım ev ise benim çamaşır dahi kurutamıyorum"

Güvenlik elemanlı ve kapalı konut yaşam alanlarında güvenlik mekânın normatif pratiklerinin korunmasında da etkili olabilmektedir. Konut sakinlerinin, kendi yaşam alanlarında davranış değişikliğine gitmelerine sebep olan, güvenlik görevlilerinin uyarıları, mekânın getirdiği normatif bir davranışların oluşmasına sebep olabilmektedir.

"Kadın 5: mesela halıma bi şey dökülse asıp kurutamıyorum... müdahale ediliyor dış görünüşü bozuyorsun diyor bozamazsin mesela”

Komşuluk ilişkilerinde yaşanan problemler güvenlik işleyişi üzerinden dolaylı olarak çözüme ulaştırılmaya çalışılmaktadır. Sorun yaşayan bireyler kendi aralarındaki sorunu çözümünde karşılıklı iletişim yerine güvenlik aracılığıyla çözüm bulmaktadırlar. Katılımcının bebeklerinin ağlaması sonucu komşuluk ilişkisi içerisindeki gürültüye dayalı bir sorunun üçüncü bir aracıyla yani güvenlik uyarısıyla çözüm bulunmaya çalışılması, katılımcının utanmak gibi olumsuz duygu deneyimi yaşamasına yol açmıştır. Bu gerilim halinin katılımcının benzer şekilde davranış değişikliğine gitmesinde etkili olduğu iddia edilebilir.

"Kadın 1: mesela rahatsız olduğum şeyler var sorun yaşadı̆̆ımız şeyler var. Bebek (isim çıkarılmıştır) doğduğunda gürültü oluyor haliyle alttaki komşuyla sorun yaşadık. Çocuk gürültü yapıyor diye bir sürü şikâyet aldık işte yönetime şikâyet edildik işte güvenlik bizi çok fazla arad. Bizi utandırdı tabi bu durum", 


\section{İole yaşam, ayrıcalıklı olmak mı yoksa hapsolmak mı?}

Kapalı konut yaşam alanında konut sakinlerinin, fiziksel olarak bu tür kapalı mekânlara dair, mekân dışında yaşayanlarla olan sosyal ilişkilerinde yeni anlamlandırmalara gitmelerine neden olmaktadır:

"Erkek 3: her yerde yakınlarda cami var ĕger uzaksa cami yapılmasında sakınca yok. Ama varsa yakında cami sitenin kapısının önünde cami varsa bence daha hayırlıdır. Çünkü başka insanlarla tanışırsin çünkü burda kendini hapsetmişsin bi şeyin içine bu tip sitelerde yaşamak zaten sıkıntılı iken kendini artık toplumdan tamamen soyutlamış oluyorsun"

Katılımcı, konut yaşam alanları içinde olan ibadethanede dini pratikleri yerine getirme eylemini yine dini bir referansla "hayırlı olanın ne olduğu" bağlamında uygun bulmadığını dile getirmektedir. Uygun olan sosyalleşmenin farklılıklarla temas üzerinden olacağını ve dini öğretinin de bunu önerdiğini ifade etmiştir. Katılımcı için dini öğretilerle gelen yaşam tarzıyla konut yaşam alanının sunduğu yaşam tarzı arasında uyuşmazlık bulunmaktadır:

"Kadin 2: burda siteye geldik bu sitenin sosyal alanları arasinda hapsolduk orda olanaklarım yoktu ama çocuğumla daha büyük bir parka sahile gidebiliyordum

$R$ : sosyal alanlar arasında hapsolmayı açar mısın?

Kadın 2: Çocuğumu alıp aveme dışında bir yere gidemiyorum. Araba kullanabiliyorum ama diyorum ki gideyim boş ver gitmeyeyim mecbur buraya hapsolduk. Eski evimden daha memnundum sahile inip hava alma çay bahçelerine gidip cay içmek bu site hayatını çocuğum için geldim benim özentim yok havuzum olsun da fitnısım olsun da zaten kullanmıyorum”

Katılımcıların GYDK Konutlarda yaşam tüketim pratiğini bir tercih olmanın ötesinde zorunluluk olarak ifade ettikleri "güvenli bir şekilde çocuk yetiştirme" söylemi bu alıntıda "hapsolmak" söylemini yanına almaktadır. Hapsolmak söylemi, ebeveynlerin kendileri için bir şeyler yapmaktan vazgeçerek çocukları için konut yaşamını tercih etme zorunluluğu olarak ifade edilmektedir. Katılımcılar "hapsolma" söylemiyle kapalı konut yaşam alanlarının kendilerinin dışarıda olma, başkalarıyla sosyal ilişski içinde olma deneyimlerini karşılayamadığını ifade etmektedir. Fiziksel olarak kapalı bir alanda yaşam, içeriden dışarıya fiziksel geçişleri sınırlandırdığı gibi izole olma halinin sembolik olarak işaretlediği farklı anlamlarda ortaya çıkmaktadır. Dışardan gelenin içeridekine ulaşmasının güvenlik endişesi üzerinden uzun ve zorlu olması katılımcı için ayrıcalıklı görünmeyi işaretlemektedir. $\mathrm{Bu}$ durum katılımcı için olumsuz algıya neden olmaktadır.

"Kadın 2: böyle olunca sanki biz çok ayrıcalıkllyız sanki bize ulaşmak çok zor şeyi çıkıyor. Kimi kimden koruyoruz ben buna karşıyım bu kadar olmamall. Bunu ben yönetimle konuştum bu kadar olmaz dedim biz büyük site değiliz herkes birbirini taniyor ne gerek var buna bunun adı kusura bakmayın görgüsüzlük özentidir dedim güvenlik değil"

Katılımcının "kimi kimden koruyoruz" ifadesi içerideki ve dışardaki üzerine yapılan kimlik atıflarına birer gönderme olarak düşünülebilir. Katılımcı için ayrıcalıklı olma ise hali korunan ve zarar veren şeklinde bir ayrımın oluşması olarak algılanmıştır.

"Erkek 3: sen şimdi bizim sitenin duvarlarl üzerinde bir de tel örgü var nerdeyse hapishane seviyesinde koruma var. Ee beni şehirden bu kadar ayrıştırdiğın zaman beni de dışarıya karşı antipatik yapıyorsun.

$R$ : dlşardakiler ne düşünüyor?

Erkek 3: dışardan bakan adama da dişardan geçen kişiye de bu duvarlarla tel örgülerle bir şey yaratıyorsun bir ayrıcalık ortaya çıkıyor" 
Katılımcı mekânın, mekân dışındakiler tarafından olumsuz algılandığını mekânın fiziksel özellikleri bağlamında ifade edilmektedir. İçeride olmanın aşırı derecede korunaklı olmasını dışarı ile ilişsilerin kesilmesi, bazı insanların diğerlerine göre daha fazla korunmaya değer olduğu izlenimi ile ayrıcalıklı olmaya doğru gidebileceğini ve sonuç olarak dışarıdakinin antipatisine neden olacağını ifade etmiştir.

\section{TARTIŞMA, SONUÇ VE ÖNERİLER}

GYDK Konut yaşam alanlarında ikame eden katılımcı evli çiftlerin, bu tarz yaşam alanlarında ev sahibi olma tüketim pratiğini tercihten ziyade zorunlu kılan birtakım etkenler üzerinden anlamlandırdıklarını gözlemledik. Katılımcılar, ebeveyn kimliği üzerinden bu konut yaşam alanlarında güvenli bir ortamda çocuk yetiştirme imkânına sahip oldukları algısına sahiptirler. Yaşam alanında belli insanlarla devamlı karşılaşma, karşılaştıkları insanlarla benzer yaş, eğitim, ekonomik seviyelerde olmaları, dışarıdan girişlerin, belli seçici geçirgen şartlar dahilinde olması bu güvende hissetme durumunu olumlu yönde etkilemektedir. Böylece bu tür konutlara sahip olma tüketim pratiği katılımcılar tarafından bir tercihten öte zorunluluk olarak algılanmaktadır. Konut yaşam alanlarında her konut sahibine sunulan otopark kullanım imkânına katılımcılar tarafından şehir hayatında insanca yaşama şartı gibi modern şehir hayatının sunduğu kimliklerle oluşan sembolik bir anlam yüklenerek bu tüketim pratiği zorunluluğa dönüşmektedir. Bulgular, endişe ve korkuları giderecek konut yaşam alanı ile zorunlu ihtiyaç arasında doğrudan ilişki kurulduğunu göstermesi açısından Bilgin'in (1991) işaret ettiği eşya ile ihtiyaç arasındaki doğrudan kurulan zorunluluk ilişkisiyle örtüşmektedir. Fakat bulgularda kurulan eşya-ihtiyaç ilişkisi ile bu ilişki kurulumunun farklılaştığı iddia edilebilir. Otopark sahibi olmanın insanca yaşamaya dair sembolik bir ihtiyacı karşılıyor olması Baudrillard'ın (1997) vurguladığı gibi eşyanın sosyal hayatta algılanışı ve sınıfsal yeri üzerinden taşıdığı anlamıyla zorunluluk ve ihtiyaç kavramının muğlaklaştı̆̆ını göstermektedir. Konut yaşam alanının sunduğu yaşam tarzı bu muğlaklıkta düzenleyici ve rehberlik edici bir model haline gelmiştir. Kadın kimliğinin performe edilmesinde bu model kendini göstermektedir. Sakinleri, konut yaşam alanının sunduğu spor, koşu, açık hava havuzda yüzme yaşam tarzı pratiği imkânlarına sahiptir. Kadınların bu pratikleri açık alanda "rahat bir şekilde" deneyimlemeleri, yaşam alanının kimliği performe edebilme imkânı olarak algılanması sembolik anlamda bu tüketim pratiğini zorunlu hale getirebilmektedir. Bu sembolik anlamlarla oluşan zorunluluk haline gelmiş tüketim pratiğine yüklenen anlamı Dittmar'ın (2008) malvarlığının psikolojik fonksiyonlarını işlevsel ve sembolik olarak ikiye ayırdığı ve çeşitli saha araştırmaları ile desteklediği bütünleşik modelle açıklanabilir. Malvarlığının psikolojik fonksiyonlarından biri de kimlikle ilişkilidir. Dittmar'ın da (2008) modelinde iddia ettiği gibi insanlar materyalleri, sadece kendilerini daha iyi, daha konforda hissetmek gibi eşyanın işlevselliğiyle ilişkili olarak anlamlandırmamış aynı zamanda eşyayı sosyal bir gruba ait olma, statü elde etme gibi kimlik dinamikleriyle de ilişkili olarak değerlendirmiş̧lerdir.

Katılımcıların konut yaşam alanının dışındaki mekânlarla ilgili bir takım olumsuz atıflar yaptıkları gözlemledik. Dışarıdaki mekânlar, tekinsiz, tehlikeli, güvenliksiz, kalabalık, kontrol edilemeyen, çocuk yetiştirmek için hatta araba park etmek için bile uygun olmayan ortamlar olarak işaretlenmiştir. Katılımcıların sitenin dışında olanları dolaylı olarak rahatsız edici olan, çocuk yetiştirme ve bakım vermede yetersiz olanlar şeklinde tanımlandıkları, diğer taraftan kendi konut yaşam alanlarında olanları ise saygılı, hoş vakit geçirilen, suçtan uzakta olan, güvenli olan şeklinde işaretledikleri tespitlerimiz arasında yer almaktadır. Mekâna bağglı sosyal ilişkilerde içerisi ve dışarısının oluşmasıyla birlikte, tanıdık olanla yabancı olan arasında karşılaştırmalar yapılmaktadır (Fried, 2000, s.108). Site içinde iç grubun yaşadığ yerler güven duygusu yaratan yerler ancak konut alanı dışındakiler ise tehlike duygusunun yaşanıldığı yerler olarak sembolize edilmektedir. Dışarıya ait bütün bu olumsuz 
betimlemelere karş1lık konut yaşam alanındakilerin bu olumsuz özelliklere sahip olmadığının ve içeridekilerinin kendileri gibi olduğunun katılımcılar tarafından vurgulanması, sosyal kimlik kuramı temel varsayımlarını destekler niteliktedir. Konut yaşam alanında yaşayanların birbirlerine saygılı olması, "bizim gibi insanlar" ifadeleri ile işaretlenmesi sosyal kimlik kuramının, aynı sosyal kategori içinde olanların kendilerini olabildiğince benzerlikler üzerinden kurulması varsayımıyla örtüşmektedir.

Alver (2013) GYDK konutlar üzerine yaptığı sosyolojik araştırmasında, bu tür konutların sayılarının artmaya başlaması ve giderek artan fiyatlarda satılabilmesinin nedenlerinden birini, konut dışındaki yaşama dair güçlü ve kurumsal olumsuz sembolik anlamları olan söylemlerin oluşturulması olarak görmektedir. Konut dışındaki hayatın "kaotik, yaşanılamaz, tekinsiz, kalabalık, kontrol dişı, insani olmayan bir yaşam şeklinde olduğu kurumsal bir ağız birliği" içinde devamlı dile getirilmesi ile bu söylemin kuvvetlendirdiğini iddia etmektedir. Görüşmelerin analizi esnasında, katılımcıların kendi iddialarını, konut yaşam alanı dışında, sokakta olan çocukların kaçırıldığına dair haberlerden örneklerle, dışarıdaki suç oranı hakkında görüşlerini olabildiğince nesnel bilgilerle güçlendirdiklerini gözlemledik. Dışarıda olanlar homojenleştirilerek kendi içlerindeki özgün yaşam tarzları göz ardı edilebilecek hatta yargılanabilir şekildedir. Sosyal kimlik kuramı bağlamında incelendiğinde iç grubun kendini dış gruptan giderek farklılaştırdığı iddia edebilmekteyiz. Bu farklılaşmanın sonucu olarak, mekânların yükssek duvarlar ile dışarıdan fiziksel olarak ayrıştırılmasının ve mekânda güvenlik önlemleri alınmasının meşru zemininin oluşturulduğu şeklinde yorumlanabilir.

Güvenlik elemanlarının varlığı, şifreli, turnikeli içeriye girebilmeyle ilgili işleyişler, yüksek duvarlar ve kamera kontrol sistemleri, konutların güvenliğini işaretlemektedir. Fakat bunun yanında insanların yaşam pratiklerinde ve anlamlandırmalarında düzenleyici role de sahip olabilmektedir. $\mathrm{Bu}$ düzenleyici rollerden biri güvenlik işleyişiyle ortaya çıkan ve insanların alansallık algısındaki düzenleyici roldür. Alansallık, insanı ve eşyayı diğer insanlardan ve eşyalardan ayırdığı gibi dışarı ile bağlantı noktaları da oluşturmaktadır (Göregenli, 2010, s.107). Mutfakta, salonda ya da yatak odasında olsun bir evin içindeki eşyaların hangi odada yer alıyorsa, o eşyalardan hangisinin ev sahipleri hangisinin misafirler tarafından kullanılabilir olacağı hakkında sembolik sınırlar bulunmaktadır (Nasır, Öğüt \& Gürel, 2015). Yüksek duvarlar, turnikeli ve şifreli içeriye geçiş sistemleri, kameralar, alansallık ile bu mekânların hem sahiplerinin olduğuna dair mesaj vermekte hem de mekânın içerisi ve dışarısı ayrımına sebep olmaktadır. Bu ayrımla birlikte misafirlerinin güvenlik kontrolünden geçerek, ev sahiplerinden onay alınarak içeriye alınmaları dışardan gelenin, misafir olarak ev sahibinden beklediği ağırlanma, hoş karşılanma algısında yeni düzenlemelere gitmesi gerektiği anlamına gelmektedir. Misafirlerden beklenen bu yeni norma dair çıkarımı şu örnekle gösterebiliriz. Ev sahibi, aile büyügü misafirlerini kendi evinin kapısında karşılamak yerine güvenlik işleyişlerinden muaf tutulması için evden çıkıp güvenliğin bulunduğu yerde misafirlerini karşılamak gibi yeni bir davranış durumu sergileyebilmektedir. Mekânın öne sürdüğü ideal yaşam tarzı normlarını tam olarak benimsemek kolay gerçekleşen bir süreç değildir. Balkona halı, çamaşır asmak gibi konut sakinlerinin kendi mahremiyet alanları olarak evlerinde yaptıkları eylemler, konut yaşam alanının belirlediği ideal yaşam tarzının dışında kalmaktadır. Bu sebeple konut sakinlerinden davranış düzenlemelerine gitmeleri beklenmektedir.

Türkiye genelinde GYDK konutlarda yaşayanların çoğu bu yaşam tarzına ilk defa dahil olmuştur (Öncü, 2005, s. 88). GYDK konut yaşam alanları deneyiminden önce gerek apartman hayatı gerek mahalle kültürü ile yetişen neslin, bu yeni yaşam alanlarına geçişlerinde birtakım çatışmaların yaşanmakta olduğu gözlemlenmiştir. Katılımcılarda bu çatışmalar sonucu, konut yaşam alanına dair izole yaşam ve hapsolma söylemleri oluştuğunu 
da gözlemledik. Katılımcılar için konut yaşam alanlarının dışardakiyle mesafeli, sınıfsal işaretleri olan seçici yaşam tarzı, konut sakinleri tarafından algılanan izole ve ayrıcalıklı olmayı içeren bir takım sembolik anlamları bulunmaktadır. Bulgularımız, Ehwi ve arkadaşlarının (2019) Gana'da insanların buralarda yaşamayı tercih etme neden olarak gösterdikleri güvenlik, ayrıcalıklı olma isteği, çocuklar için güvenli alan faktörleriyle örtüşmektedir. Konut yaşam alanları içinde yer alan camilerde ibadetin dini öğretilerin farklı sınıfsal kesimlerin bir araya gelmesi yönünde sunduğu yaşam tarzı bu tür konut yaşam tarzlarıyla çelişebilmektedir. Bu çelişkilerin özellikle geleneksel ve dini endişeleri barındıran mütevazı yaşam tarzlarının bu yeni yaşam mekânlarında deneyimlenmesi sonucu ortaya çıkmaktadır. $\mathrm{Bu}$ durum, geleneksel kültür ile yeni konut yaşam alanlarına ait normların örtüşmemesi şeklinde yorumlanabilir. Konut şirketleri bu çatışmalar üzerine mahalle kültürü, muhafazakâr yaşam alanları söylemleri üzerinden yaşam alanları pazarlamaya başlamışlardır. Sunulan bu söylemler ve bu konutlarda yaşayanların deneyimleriyle ortaya çıkan yaşam tarzı kıyaslamalarının, ileride araştırmaya açık konular olacağına işaret etmektedir. Katılımcıların konut yaşam alanlarında davranış düzenlemelerine gidiyor olmalarını tetikleyen endişe, utanma, öfke, mahcubiyet gibi sosyal duygu deneyimler yaşamaktadırlar. $\mathrm{Bu}$ tür konutlarda yaşayanların bu yaşam tarzı üzerinden deneyimledikleri sosyal duygular üzerine incelemeler yapılmasının, yaşam tarzı üzerine yapılan araştırmalar önemli bir katkı sağladığ düşünülmektedir. Bu alandaki çalışmalara bir diğer katk1 ise tüketim pratiği olarak bu tür konut yaşam alanlarının potansiyel sakinlerine sunduğu gündelik yaşam tarzını konut reklamları üzerinden analizi ile şimdilerde bu konutlarda yaşayanların gündelik yaşamlarındaki değişimlerin karşılaştırmalı incelenmesi şeklinde olabilir. Covid-19 virüsü kaynaklı pandemi süreci sağlık açısından güvenli alan ihtiyacını da gün yüzüne çıkarmıştır. İnsanların kendi mikrosistemleri (ev, yaşam alanları) bulaşıcı hastalıklardan uzak ve izole olma özelliğine sahip olmasının, iyilik halleri üzerinde önemli etkileri olduğu görülmüştür (Tanhan ve ark., 2020). Pandemi bağlamında katılımcıların bu tür konut yaşam alanlarına dair anlamlandırmalarını incelemenin, yine önemli inceleme konularından biri olacağını düşünmekteyiz.

Çalışmanın araştırmacıları bu tür konut yaşam alanlarında doğrudan bir yaşam deneyimine sahip olmamışlardır. Dolayısıyla bu tür yaşam alanlarından elde edilen verilerin analizinde araştırmacıların farklı olan, değişen, eklenen insan davranışlarına ve sosyal ilişkilere odaklanması kaçınılmaz olmuştur. Verilerin elde edilmesi sırasında katılımcıların konut yaşam alanlarının fiziksel imkânlarına çok fazla odaklandıkları ve ifadelerinde bu imkanların sıklıkla yer aldığı gözlemlenmiştir. Bu yaşam alanlarının sunduğu imkanlara odaklanmanın temel sebeplerinin, bu mekanların, katılımcıları ekonomik durumlarına göre yaşam tarzlarında yeni düzenlemelere gitmek zorunda bırakması ve kredi kullanma üzerinden borçlanmalarına neden olması olabileceği ve bununla bağlantılı olarak da yüksek maliyetli bu tüketim pratiğini anlamlandırırken bu değişimler karşılığında nelere sahip olduklarını ifade etme ve gerekçelendirme çabaları olduğu düşünülebilir. 


\section{KAYNAKÇA}

Alver, K. (2013). Steril hayatlar. İstanbul: Hece Yayınları.

Azak, Y. (2020). İstanbul'da yaşayan orta yaş ve üzeri yerleşik ailelerin Suriyeli göçmenler bağlamında kolektif sahiplik algısı. Psikoloji Çalışmaları Dergisi, basım aşamasında

Bali, R. (2002). Tarz-ı hayat'tan life style'a yeni seçkinler, yeni mekânlar, yeni yaşamlar. İstanbul: İletişim Yayınları.

Baudrillard, J. (1997). Tüketim toplumu: Söylenceleri, yapıları. (A. Şenel Çev.). İstanbul: Ayrıntı. (Orijinal eserin yayın tarihi 1970)

Baudrillard, J. (2004). Nesneler sistemi. (O. Adanır, Çev.). İstanbul: Boğaziçi Üniversitesi Yayınları. (Orijinal eserin yayın tarihi 1968).

Bauman, Z. (2005). Bireyselleşmiş toplum. (Y. Alogan, Çev.). İstanbul: Ayrıntı. (Orijinal eserin yayın tarihi 2001)

Bilgin, N. (1991). Eşya ve insan. Ankara: Gündoğan Yayınları.

Bocock, R. (1997). Tüketim. (İ. Kutluk, Çev.). Ankara: Dost Kitabevi. (Orijinal eserin yayın tarihi 1993).

Chaney, D. (1999). Yaşam tarzları. (İ. Kutluk, Çev.). Ankara: $\quad$ Dost $\quad$ Kitabevi. （Orijinal eserin yayın tarihi 2001).

Dittmar, H. (2008). To have is to be? Psychological functions of material possessions. H. Dittmar (Ed.) Consumer Culture, Identity and Well-Being içinde (s. 25-43). New York: Taylor and Francis Group.

Dittmar, H. (2008). Understanding the impact of consumer culture. H. Dittmar (Ed.), Consumer Culture, Identity and Well-Being içinde (s. 1-25). New York: Taylor and Francis.

Douglas, M. ve Isherwood, B. (1999). Tüketim antropolojisi. (E. Aytekin Çev.). Ankara: Dost Kitabevi, (Orijinal eserin yayın tarihi 1996).

Dovey, K. (1985). The house as symbol of social structure. C. M. Werner (Ed.), Home Environment içinde (s. 33-64). New York: Plenum Press.

Ehwi, Richmond J., Morrison N. ve Tyler P. (2019) Gated communities and land administration challenges in Ghana: reappraising the reasons why people move into gated communities, Housing Studies, doi: 10.1080/02673037.2019.1702927.

Elo, S. ve Kyngäs, H. (2008). The qualitative content analysis process. Journal of Advanced Nursing, 62 (1) 107-115. doi: 10.1111/j.1365-2648.2007.04569

Elo, S., Kääriäinen, M., Kanste, O., Pölkki, T., Utriainen, K. ve Kyngäs, $\quad$ H. （2014). Qualitative content analysis: A focus on trustworhtiness. SAGE Open, 11 (4) 67-82. doi: $10.1177 / 2158244014522633$

Erlingsson, C. ve Brysiewicz, P. (2017). A hands-on guide to doing content analysis. African Journal of Emergency Medicine, 7(1) 93-99. doi: 10.1016/j.afjem.2017.08.001

Featherstone, M. (1996). Tüketim toplumu ve postmodernizm. (M. Küçük, Çev.). İstanbul: Ayrıntı Yayıncılık. (Orijinal eserin yayın tarihi 2007).

Fried, M. (2000). Residential attachment: Sources of residential and community satisfaction. Journal of Social Issues, 3(38), 107-119. 
Frith, H. ve Gleeson, K. (2004). Clothing and embodiment: Men managing body image and appearance. Psychology of Men and Masculinity. doi: 10.1037/1524-9220.5.1.40

Göregenli, M. (2010). Çevre psikolojisi: Insan ve Mekan İlişkileri. İstanbul: İstanbul Bilgi Üniversitesi.

Hogg, M. ve Abrams, D. (1992). Social identifications: A social psychology of intergroup relations and group process (3. Bask1). New York: Routledge.

Krippendorff, K (2004). Content analysis: An Introduction To Its Methodology. $\quad$ London: Sage Publications.

Nasır, E. B., Öğ̈̈t, Ş., \& Gürel, M. (2015). Changing uses of the middle-class living room in Turkey: The transformation of the closed-salon phenomenon., 15-19. Intercultural Understanding, 15-19

Neuendorf, K. A. (2012). The Content Analysis Guidebook. London: Sage Publications

Orçan, M. (2004). Osmanlı'dan Günümüze, Modern Türk Tüketim Kültürü. Ankara: Kadim Yayınevi.

Öncü, A. (1999). İdealinizdeki ev mitolojisi. Birikim Dergisi, 123, 26-34.

Öncü, A. (2005). "İdealinizdeki ev" mitolojisi kültürel sınırları aşarak İstanbul'a ulaştı. A. Öncü, ve P. Weyland (Ed.) Mekan, Kültür, Iktidar: Küreselleşen Kentlerde Yeni Kimlikler içinde (ss. 85-103). İstanbul: İletişim.

Reicher, S. D., Spears, R., ve Postmes, T. (1995). A social identiy model of deindividuation phenomena. European Review of Social Psychology, 6(1), 161-198.

Robinson, O. C. (2014). Sampling in interview-based qualitative research: A theoretical and practical guide. Qualitative Research in Psychology, 11(1), 25-41.

Sixsmith, J. (1986). The meaning of home. Journal of Environmental Psychology,6, 281-298.

Tajfel H. ve Forgas J. (1981). Social categorizations: Cognitions, values and groups. J. Forgas (Ed.), Perspectives of Everyday Understandings içinde (ss. 114). London: London Academic Press.

Tanhan, A. (2020). COVID-19 sürecinde online seslifoto (OSF) yöntemiyle biyopsikososyal manevi ve ekonomik meseleleri ve genel iyi oluş düzeyini ele almak: OSF'nin Türkçeye uyarlanması. [Utilizing online photovoice (OPV) methodology to address biopsychosocial spiritual economic issues and wellbeing during COVID-19: Adapting OPV to Turkish.] Turkish Studies, 15(4), 1029-1086. doi: 10.7827/TurkishStudies.44451

Tanhan, A., Yavuz, F. K., Young, S. J., Nalbant, A., Arslan, G., Yııldırım, M., . . Çiçek, İ. (2020). A proposed framework based on literature review of online contextual mental health services to enhance wellbeing and address psychopathology during COVID-19. Electronic Journal of General Medicine, 17(6). doi:10.29333/ejgm/8316

Taylor, S. (2005). Identity trouble and opportunity in women's narratives of residence. Auto Biography Journal, (13), 249-265.

Turner, H. T. (1986). The social identity theory of intergroup behavior. S. W. Austin (Ed.), Psychology of Intergroup Relations içinde (ss. 72- 85). Chicago: Nelson-Hall.

Turnock, R. (2007). Television and Consumer Culture. New York: I.B.Tauris. 
Ek 1. Tüm kategorilerin temalara göre dağılımı

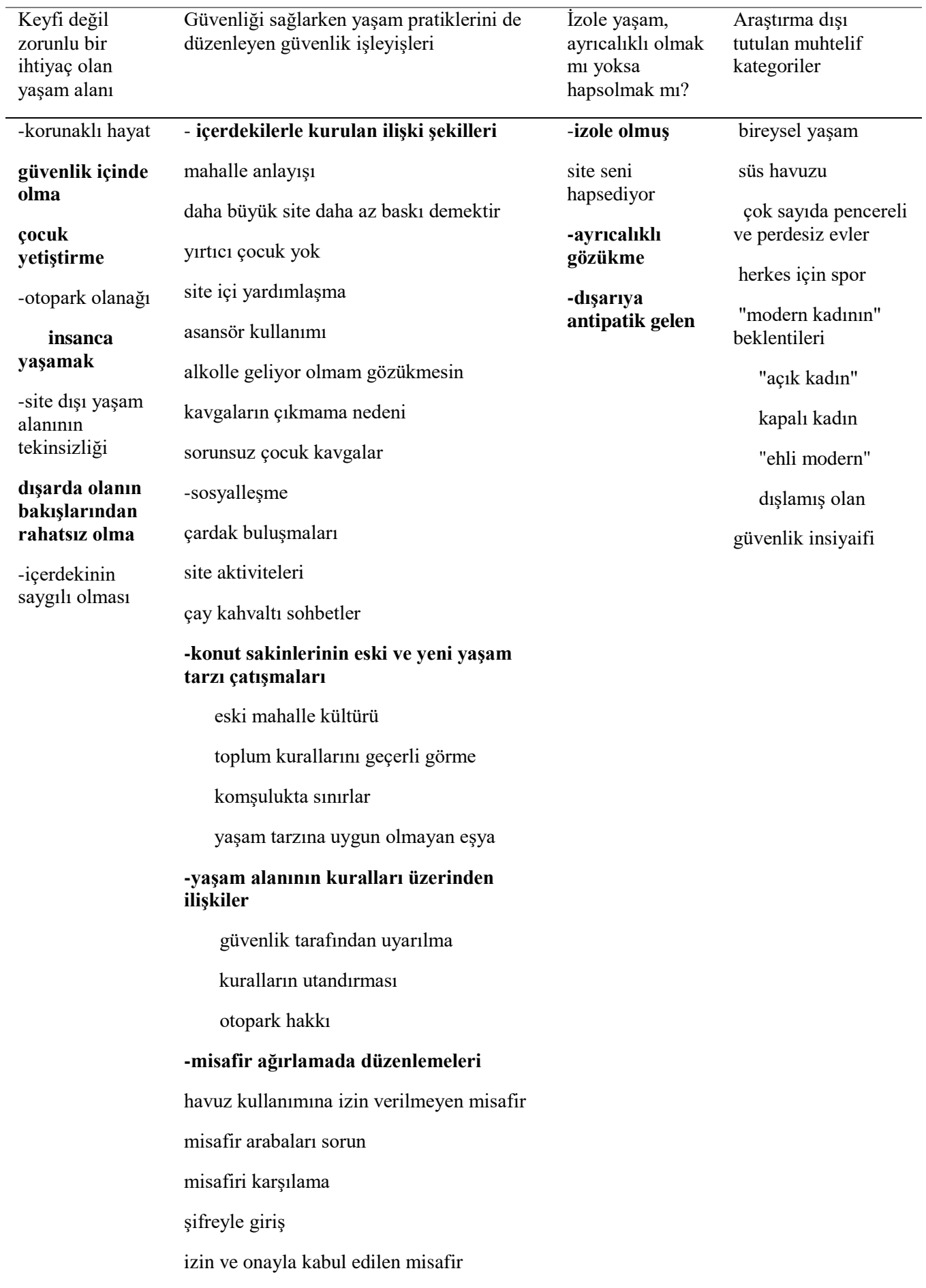

Not: Ana kategoriler görünme yoğunluğuna göre sıralanmış ve koyu renkle gösterilmiştir.

Ek 2. Araştırmada kullanılan görüşme soruları

1. Yaşadığınız konutun özelliklerinden biraz bahseder misiniz?

2. Bu tür sitelerle ilgili en çok sevdiğiniz şeyin ne olduğunu söyler misiniz?

3. Bu siteyi tercih etme sebepleri ve karar verme süreçlerinizden bahseder misiniz?

4. Sitede görmekten rahatsız olduğunuz şeyler nelerdir?

5. Oturduğunuz sitede yaşayan kişilerden biraz bahseder misiniz?

6. Site dışından misafirleriniz yaşadığınız site hakkında nasıl yorumlar yapıyorlar? 